\title{
Main Determinants of Georgia's Transit Function Development
}

\author{
Irakli Danelia, (PhD student) \\ Tbilisi State University, Georgia
}

Doi: 10.19044/esj.2017.v13n31p79 URL:http://dx.doi.org/10.19044/esj.2017.v13n31p79

\begin{abstract}
Due to the strategically important geographical location, Georgia has a key transit function throughout the Caucasus and beyond between Europe and Asia, but unfortunately transit potential of the country is used only partially. Nowadays, prospects and problems of the transit function for small country with very limited resources such as Georgia are vital issues for the country's economy. Because of this, the purpous of the study is to identify the major determinants that play a crucial role in the development of transit function of the country. based on practical and theoretical significance of the research we used systemic, historical and logical generalization methods of research in the performance of the work, scientific abstraction, analysis and synthesis methods are also used.
\end{abstract}

Keywords: Transit, Geopolitics, Logistics, International transportation, Economics

\section{Introduction}

Depending on geostrategic location of Georgia, the development of the country's economy is directly related to the efficient use of transit function (Chagelishvili, L. 2009). The realization and development of Georgia's transport potential began in the 90 s of the 20 th century and is still one of the important components of the country's economy. Georgia is key part of the Europe-Caucasus-Asia transport corridor. The corridor including the Georgian section, consists of two major components: TRACECA and East-West Energy Corridor (Economic Commision for Europe, 2003).

In 1993 European Commission convened by the conference adopted a declaration, which the South Caucasus and Central Asian countries in the region have worked out the regional program - TRACECA1- and its mission is to support reconstruction and modernization of traditional types of Transport-railways, roads, ports, terminals in the corridor to join the European one (www.traceca-org.org). The TRACECA program quickly 
acquired dynamism and international recognition with it (Gegeshidze, A. 2007).

I.

In parallel with the TRACECA program, the projects have been developed to export oil from Azerbaijan to Georgia on the international market. Construction of Baku-Supsa oil pipeline started ended in 1999 and the transit corridor acquired a very important energy aspect. At the same time, the Poti railway-ferry crossing constructed within TRACECA program, by which Georgia has established as an internationally recognized transit function (www.traceca-org.org)

A geo-strategically important decision was taken to strengthen the Georgian transit corridor's function when the transport corridor was implemented by Baku-Tbilisi-Ceyhan (BTC) and South Caucasus pipeline Baku-Tbilisi-Erzurum (Shah-Deniz) project of two major regional oil pipelines (www.gogc.ge) All three objects are important not only to increase Georgia's transit potential but also to improve regional integration. This is the main task of long-term strategic partnership among Georgia, Azerbaijan and Turkey in the development of the energy corridor (Javakhishvili, R. 2009).

The BTC pipeline is the first and shortest route for oil transportation between Caspian and Mediterranean seas (Cornell, S.E., Tsereteli, M. 2005). The length of the pipeline is $1768 \mathrm{~km}$, Pipeline throughput Only Azeri oil transducers are $50 \mathrm{mln}$. Tons per year, and if the Kazakh and Turkmen oil add totally will makes up 80 mln tones per year (www.bp.com). In March 2000, Georgia agreed on a meeting of the Presidents of Georgia and Azerbaijan in Georgia, Georgia will receive \$2100,000,000 during the 40year contract, which means 62,5 million dollars income annually. In the near future, Kazakhstan oil exports are also planned through Baku-TbilisiCeyhan, which will create conditions for integrating this country into regional integration processes (www.gogc.ge).

Besides geo-strategically and internationally important oil pipelines, two major pipelines are located in Georgia: North-South and Baku-TbilisiErzurum gas pipelines (Sladkovski, A., Gelashvili, O., Goletiani, G. 2014). The North-South main gas pipeline was built in the second half of the 20th century and is transporting Russian gas to Georgia and Armenia. The length of the Georgian section of the pipeline is $221 \mathrm{~km}$. As for the South Caucasus gas pipeline, it will transport gas from the Shah-Deniz and Caspian Sea basin to Turkey and then to Europe in distribution. The length of the Georgian section of the pipeline is $249 \mathrm{~km}$. (www.gogc.ge). The construction of this gas pipeline was completed in 2006. Currently its annual capacity is 6 million cubic meters. It is important to emphasize that Georgia is not only a 
transit corridor but a natural gas consumption state. Georgia has a condition to purchase $5 \%$ of the gas exported from Azerbaijan to Turkey at reasonable prices. Additionally, within 20 years of the discharge into the project, Georgia has an additional $500 \mathrm{mln}$ of natural gas from project investors. The cubic meter will be purchased at a special price.

An important part of the Eurasian transport artery between the Black and Caspian seas is the Georgian Railway connecting Europe with Central Asia and subsequent China. Its operational length is $1575 \mathrm{~km}$ ( www.railway.ge) Railroad transport has almost 140 years of history in our country and is one of the most important factors in the successful operation of the Europe-Caucasus-Asian transit corridor with its infrastructure. Currently, Georgian Railway is one of the profitable direction of the rail freight transport connecting Caspian region and Central Asia to Europethrough Poti, Batumi and Kulevi sea ports from which cargo is shipped directly from/to Bulgaria, Romania, Ukraine, Russia and Turkey ports.

Number of cargo shipments in tones (www.railway.ge)

Total Number of shipments

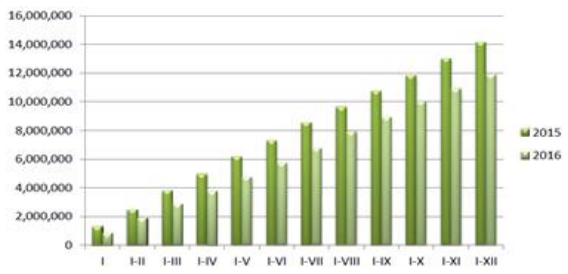

Export/Import

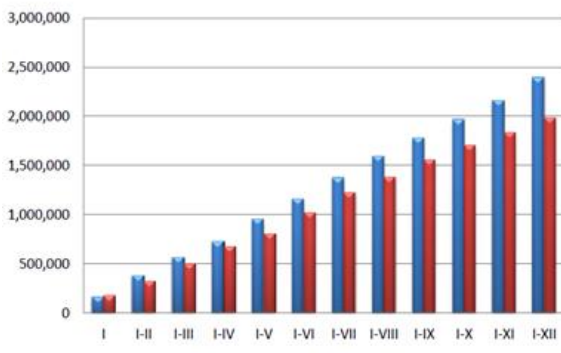

Transit

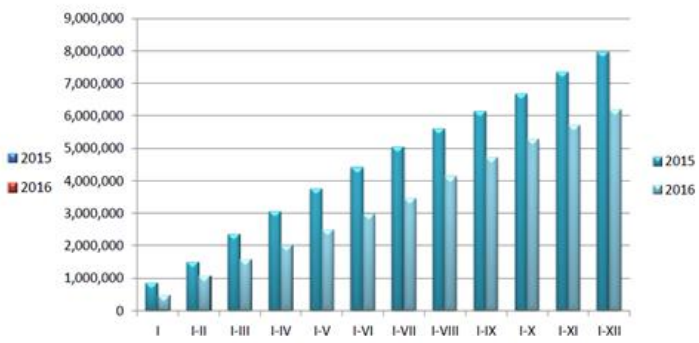

Baku-Tbilisi-Kars railway line construction project is the most important new direction not only for Georgia, but also for Azerbaijan and Turkey as well (Uysal, O, 2013). This is a railway line that lays down the railway lines of Azerbaijan, Georgia and Turkey (Samuel, L. 2008). Implementation of the project is scheduled for 2017 year. This project is expected to increase from $5 \mathrm{mln}$ to $15 \mathrm{mln}$ tonnes cargo tones (Shepard, W. 2017). Today, Transportation of liquide kargos such as oil and oil products, especially crude oil is moved from for Georgia's railroad to Pipelines. In 
particular, according to data of the first quarter of 2016, compared to the same period of 2015 , less by 1,254 million. Tons of crude oil and oil products have been transported by Railway. Thus, the international rating company FITCH reduced rating of the Georgian Railway from BB to B + (www.fitchratings.com) which was conditioned by transferring these crude oil to pipelines. The main cargo includes cereals and grain products, with a total volume of 716,356 million in 2015. Tone. According to the data of 2016, there is a sharp decline - 448,128 million. Tons. During the last few years, the volume of iron and manganese silk should be noted. From 2015 to 2016 the difference was 8,486 million tons. Despite the decline in the cargo turnover, the Georgian Railway is aiming at the current 27 million. Tone bandwidth is $100 \mathrm{mln}$ tones increase per year (www.railway.ge).

Maritime transport has a strategically important role in the Georgian economy. Poti, Batumi and Kulevi ports are important in this regard. The transit cargo passing through Georgia shipps to Varna, Constanta, Novorossiysk, Odessa and Istanbul ports.

Poti sea Port is Georgian first and largest port with crucial linkage within TRACECA. At present, the harbor consists of 2650 meters and 14 berths. Conditions for transportation of cargo are customized for transportation of dry and liquid cargo. The turnover of dry and liquid cargo in Poti port is about 600,000 TEU (TEU - twenty-foot equivalent unit). The total length of the existing bay is 2,900 meters, where more than 20 offshore lanterns are located (www.apmterminalspoti.com). In 2013 the grain processing terminal $(500,000$ tons per year capacity) was opened, which is an alternative route for the export of Central Asian wheat in the Black Sea and Mediterranean regions (Natroshvili, N. 2015).

Batumi Port, like the Poti port, operates for liquid and dry cargo, which has a capacity of $15 \mathrm{mln}$. Tons and its expected to reach $28 \mathrm{mln}$. Tones (www.batumiport.com). Hereby note that the capacity of Batumi Container Terminal is 100,000 TEUs per year. Dry cargo terminal maximum capacity of 2,0 million tons per year. Besides, Batumi Oil Terminal provides the services of oil and oil products from Kazakhstan, Azerbaijan, Turkmenistan, Georgia and other countries. Batumi oil terminal is supplied with the Georgian Railway via Wagon-Cisterns, which is underway in modern railways. The capacity of the oil terminal is about 15 million tons per year. The Batumi Oil Terminal can simultaneously vacate more than 770 wagons-cisterns in 194 wagons or cisterns (www.batumioilterminal.com).

Kulevi oil terminal capacity - allows to operate for $10 \mathrm{mln}$. tons of oil products over a year, including: $3 \mathrm{mln}$ tons of oil, $3 \mathrm{mln}$ tons of diesel and $4 \mathrm{mln}$ tons of crued oil. The total capacity of the reserve park is 320 thousand cubic meters, with a potential increase of 380 thousand tons. Production of oil products in the hour is from 1000 to 8000 cubic meters 
(www.kulevioilterminal.com) Since July 2010, the Kulevi Port has started exporting Kazakh oil. The realization of this project, which involved the need for service of large-scale tankers (more than 100,000 tons of cargo), carried the deepening of the bottom line.

According to the official statistical data below, If we totally count data of 2014 year compare to its analog data in 2015 and 2016 we will see that the total volume of turnover decreased by $2.1 \mathrm{mln}$ tons and in $2016-3.7$ mln tons. Baesed on the data of the whole year in 2014 we have dramatic decline trend by volumes of containers in the marine harbors and fluctuates from 20 to 26 per cent (www.economy.ge).

Total Handled Cargo by Sea Ports and Sea Terminals
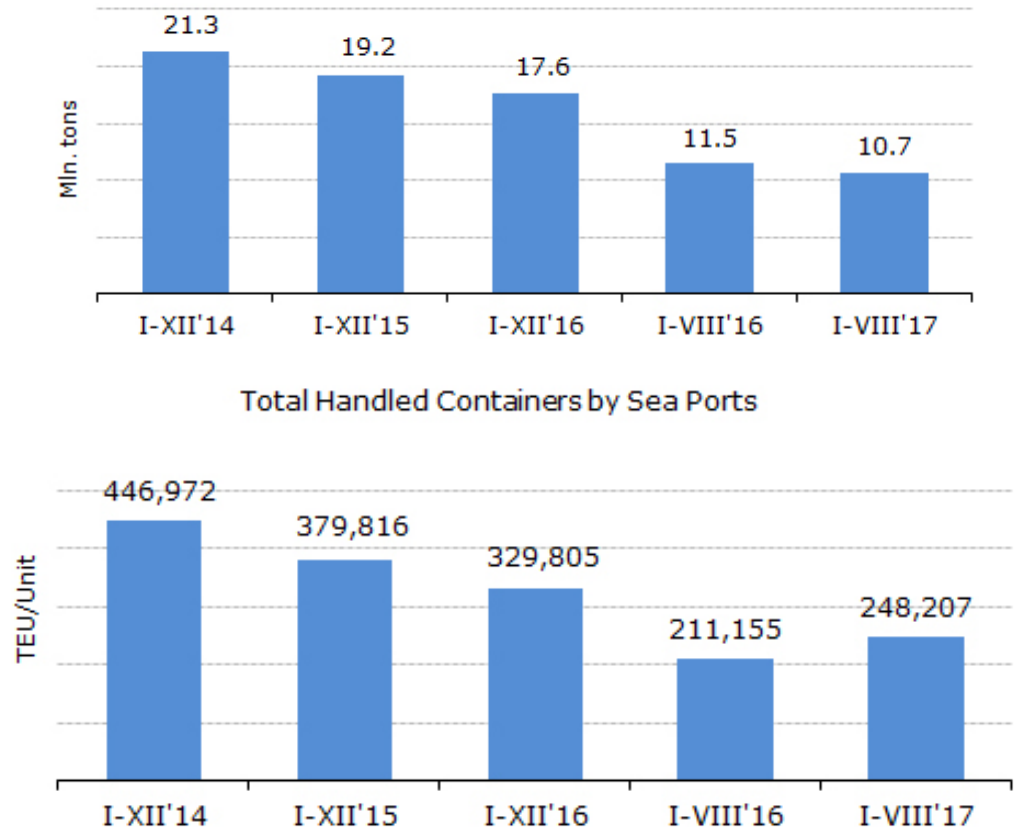

Inland transport occupies the most important place in the transport system of Georgia. During the Soviet Union, the field activity was mainly functioning within the country, after the collapse of the Soviet Union, the transport sector went into the international market. The opening of the border with Turkey has dramatically increased the activity of motor transport, thus volume of cargo shipments and cargo turnover increases accordingly. Country roads An average of 17.2 million tonnes of cargo transportation is carried out annually (www.economy.ge). Since 1990 motor vehicles have returned to its function, though it is noteworthy that most of the motorways are damaged due to the negligence. Since Georgia has acquired the status of a corridor for Asia-Europe, it has become a priority for the development of transport infrastructure. The increased requirements for motor transport have 
been put on the agenda for reconstruction of existing roads and in some cases the necessity of building new safe sections. The total length of international road on the territory of Georgia reads $1467 \mathrm{~km}$.

The turnover of transport and communications sector by 2016 was $5,8 \mathrm{bln}$. Which was $10.1 \%$ of the total turnover of the business sector. If we look at the trend below, which covers period from 1999 to 2016, its evidence that the volume of transport and communications sector turnover has grown from year to year, but in 2016 it was decreased by GEL 0.1 bln. Nevertheless, total cargo transportation from 2014 till third quarter of 2017 year has decreaseing trend (www.geostat.ge).
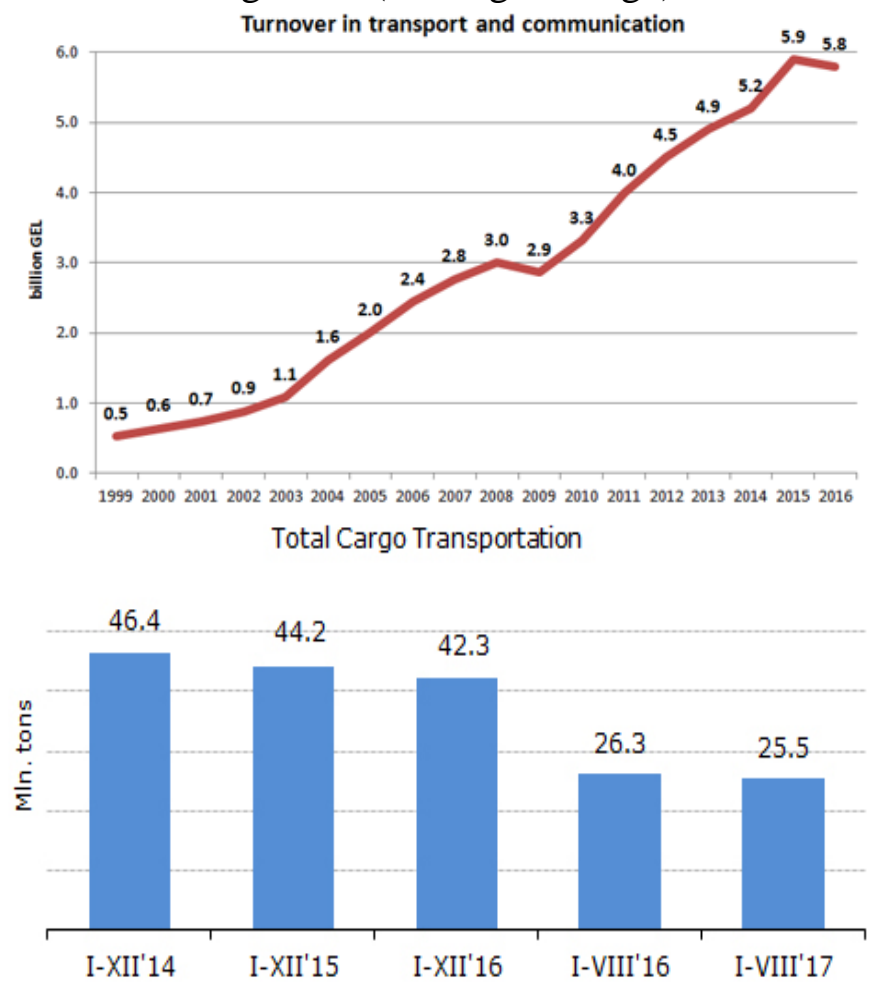

The downward trend of a cargo turn might be coused due to internalites and externalitess. This means that there are various factors that are negatively impacted on the turnover.

It is important that the transport corridors should be considered not only from the point of integration of international economic but also as the most important element of the global logistics system (National Center for Educational Quality Enhancement, 2015). In order to identify the major determinants that makes the most important influence on the development of Georgia's transit function is to put the abovementioned factors into the following levels: 
$>\quad$ International Political factor;

$>\quad$ Common economic factor;

In the international political factor we can combine strategic geopolitical interest of all countries towards to Georgia as the main gateway and the shortest route in the Caspian Sea Oil Supply System (Cornell, E. S., 1999). This geopolitical interest to Georgia is equipped with suppliers of oil and gas (Kazakhstan, Turkmenistan, Azerbaijan), Consumers (EU, Turkey), transit rival Russia and geopolitically opposing the US and Iran. Oil and gas suppliers, as well as for consumers, have a political interest towards Georgia, since the transit route passing through the Georgian port is shortest and relatively safe compared to other alternate corridors (Bertsch, Gary K. C. Craft, Scott A. Jones and Beck, M. 2000) Shortest way to transport caspean countries to Turkey goes on Armenian teritory not on Georgia, But, tense political relations between Armenia and Azerbaijan have contributed to the development of the Georgian section of the transit routing (Minasyan, S. 2016). Russia and Iran's interest in Georgia are motivated to the fact that they do not want the West and the US to deepen the political influence on the country and the entire region (Michael, P 2007) The high interest of international actors to Caspian resources contributes development of Georgian transit role and relevance, but it is not only seems to be the main determinant for a rapid development as today only $40 \%$ of transit function is used.

It is important to review and evaluate all the determinants that can be combined in the general economic factor analysis:

$>\quad$ level of integration in the international economic regulatory system;

$>\quad$ Level of Macroeconomic development;

$>\quad$ Administrative provision and Infrastructure Support Level

Participation in the International Economic Regulatory System means to have bilateral and multilateral Economic agreements with partner states. On this occasion, since 2000 year Georgia is a member of WTO. For countries with small economies, membership in this organization is considered to be profitable, since the preferred regime, protection against discrimination and equal taxes on national or imported goods promotes the purchasing power of the country as well as entrepreneurs who have a chance to get their products outside the country. In exchange for decreased tariffs, countries are increasing their profits by increased trade. The reduction of barriers is also designed to improve internal entrepreneurship. Neverhteless The Country has signed bilateral agreements on free trade with CIS member states, Turkey and has recently gaind ratification of free trade agreement with the People's Republic of China. It is also immence to mentioned that Deep and Comprehensive Free Trade Agreement with the European Union has been signed (www.dcfta.gov.ge). In contrast to other free trade 
agreements signed by Georgia, the DCFTA implies liberalization of goods as well as services. In addition, the DCFTA includes a wide range of trade related issues (eg food safety, competition policy, intellectual property protection, financial services, etc.) and provides a gradual approximation of trade legislation with the EU legislation. DCFTA allows Georgia to gradually receive three out of four freedoms of the EU internal market: free movement of goods, services and capital. Fourth freedom - free movement of people promotes visa liberalization process. In addition to the above, Georgia is signatory to all the international treaty provisions that promote the development of trade relations, for example, the most important thing is the avoidance of double taxation in the country of VAT in which one partner country no longer bids the business subject. Thus there is no significant hindering factor in terms of integration into the international economic regulatory system in terms of limiting export / import and transit cargo, on the contrary, a liberal legislative base is designed to ensure that the cargo process is uninterrupted.

The level of macroeconomic development includes all the parameters that are directly or indirectly correlated with the growth and development of the country's transit function. In macroeconomic factors we need to take into consideration the growth of trade intensity with neighboring and non-trading trade partners, ie the number of export and import cargo, as well as the frequency trajectory of transit freight in the importing or exporting countries of these cargoes. Georgia and the countries of transit cargo volume growth depends on the country's foreign trade balance, fluctuations in the exchange rate as well as growth in its main trading partner countries in the macroeconomic development speed, for example Georgia on transit routes for growth depends on macroeconomic growth of Armenia and Azerbaijan, particularly in the export and import Operations growth for Turkey, the European Union and the CIS member states of the Union whose vehicles pass through Georgian territory for transit use. It is therefore important to analyze both the monetary and fiscal policy in Georgia and its trading partner countries.

The level of macroeconomic support can not be seen without administrative and infrastructural factors. In order to focuse on Administrative and infrastructural determinants we should analyse Logistics Performance Index which is developmed by The World Bank. The Index is defined based on the qualitative and quantitative evaluations of international operators in the field of logistics in countries where operators offer different determinants to assess the country's transport capabilities. All components presented and analyzed in this index are based on international logistics companies theoretical and empirical research of practical experience. If we 
examine in detail abovementioned factor, it can be distinguished by the following elements:

$>$ Effectiveness of Customs Services and Border Management Operations;

$>\quad$ Quality of trade and transport infrastructure;

$>\quad$ The simplicity of organizing the shipment;

$>\quad$ Quality and competence of logistical service - in motor transport, forwarding and customs-brokerage service;

$>\quad$ Monitoring and control mechanisms of cargo transportation;

$>\quad$ Traffic timing and frequency of misconduct.

While discussing the administrative and infrastructural factors, it is important to consider the Local Logistics provision which describes the logistics environment in specific countries and determines the level of simplicity of all logistical operations, but according to this index we are not able to identify all aspects of the industry. It is necessary to take into consideration the material-technical capabilities of the main transportation modes and the need for their development and to identify major problems that are found in the institutional basis. It is also necessary to take into account the timely factor and cost of logistics services. The above index reviews the country's logistical position mainly on infrastructure across the country, such as ports, border crossings, and other less and less the level of insuring various logistics points and terminals across the country. Thus, in the administrative and infrastructure provisioning factors, the following micro elements may be combined:

$>\quad$ Level of costs and fees (Terminal Handling, Merchans Haulage);

$>\quad$ Intermodal infrastructure quality;

$>\quad$ Service competence and quality;

$>$ Effectiveness of Boundary procedures and time management

$>\quad$ Delaying sources (Detensions, Demurages);

$>\quad$ Changes in logistics;

$>\quad$ Supply chain continuity and reliability.

As a result of the qualitative and quantitative research conducted with all participating interdepartmental companies, Poti and Batumi Ports Managing Companies, Georgian Railways, leading international transport/logistics companies are actively operating in Georgia and Whole in the Caucasus it is clear that the level of customs spending and fees in 20122016 were not high in the country and it is quite competitive compared to the rest of Black Sea countries. Here works so called „One Window” principle which maintains simplicity of administrative operations in the minimum time by the carrier in the customs bodies. The majority of respondents support and highly appreciate the level of efficiency of customs procedures, although some of the problems related to the confederation seem to be facing both 
transportation and logistics companies in 2012 and 2016. It should also be emphasized that the vast majority of operators surveyed in 2016 confirm high percentage of shares compared with 2012 in comparison with Logistic Environmental Solutions.

Providing competitiveness and sustainability of the transit corridor of Georgia requires a lot of effort, as a result of the analysis, the following key problematic issues were identified: directly or indirectly, the possibilities for development of Country's transit functions are as follow:

$>\quad$ Frequent fluctuations in the exchange rate;

$>\quad$ Low quality of local and transit infrastructure;

$>\quad$ Monopoly situation in port and terminal service;

$>\quad$ One way tariff preferences.

Currency fluctuation is the most important factor in the formation of cargo volume in Georgia. Volume of imported goods sharply decreases owing to strengthening US dollar and EUR against Georgian lari, which eventually negatively impacts to the trade turnover. Over the last three years, Georgian Lari has been depreciated against US dollar by approx. $42 \%$.

Besides above mentioned, it is necessary to increase the quality of transit infrastructure. Therefore "corridor of values" is the guarantee of stability of the Transcaucasian region, which implies investment activities and support of precondition for transferring resources to the world market. However, the existing legacy requires reorganization. It is necessary to provide legal grounds, improve communication systems, establish banking system and insurance conditions, and regulate tariff environment, etc. Reorganize a number of issues in order to improve Georgia's transit infrastructure after an international transit corridor that will meet international standards.

The costs and fees of Georgian ports and terminals is much higher than any other port and terminal of the Black Sea (Danelia, I. 2016). This is due to the pipeline and terminal service monopolistic condition. Today, the main port of the country is the Poti sea port and Batumi Port cannot compite with it due to very limited technical facilities in last one. As a result, there is one port operator in the market that provides port services with the clients' service and establishes the so-called " Combined tariffs. This tariff is very expensive and eventually increases the imported/exported products as well as transit cargo. For this reason, there are frequent cases when Azeri and Armenian cargoes from China lie in the port of Bandar Abbas (Iran) instead of entering the Poti sea port, and from land transported by land transport, because this is significantly cheaper than in Poti port and terminal service.

For the purpose of attracting freight cargoes from Caspian Sea Countries (Kazakhstan, Turkmenistan, Azerbaijan), as a rule, special 
privileges are based on the tariff policy of carriage. At the same time, it is not recommended to encourage transportation from the West to the east, Black Sea ports terminals, via Georgia and Azerbaijan Railway to the Caspian Sea countries. A certain cargo and direction, from the West to the East, is the shipping cost 2-3 times higher than the transportation of the same nomenclature from east to west. Therefore, it is difficult to find reverse cargoes, increase efficiency of shipping, as there are no relevant mechanisms to attract cargo handling.

\section{Conclusion}

On the basis of the analysis we have concluded that the development ofGeorgia's transit function depends on many determinants. One of the most important direction is the common economic factor. From the above factor, the following major determinants identified: the level of infrastructures, the level of transport policy among neighboring states and macroeconomic growth rates in trading partner states.

Under the new Silk Road, it is of great importance that the countries involved in this transit corridor have a growing tendency of trade among each other, commonly agreed tariff policy, commonized customs procedures and common rules of cargo transportation.

Besides the political and economic problem for the successful operation of the transit corridor, it is necessary to analyze the advantages and disadvantages of competing transit corridors existing on the international level to it take into consideration for further development.

It is important to have a balanced political relationship with all the forces interested in Georgia's transit function. The correctly developed country's geopolitical strategy should include bilateral and multilateral diplomatic relations based on economic outcome, both with regional and international players that have their own geopolitical interests in relation to Georgia.

The improvement of logistical infrastructure will be of great importance to all the planned projects related to the construction of the Anaklia Deepwater Port, the formation of Poti Mega Port, the construction of Baku-Tbilisi-Kars (Lissac, S., 2008) railway route and the increased capacity of the power corridor.

Logistics Performance Index proposed by the World Bank is an important determinant in the development of Georgia's transit corridor. The analysis revealed clearlythe positive role of customs operations and border procedures; Logistics infrastructure related to vehicles; monitoring and controls of cargo turnover, service level, frontier procedures and time management, supply chain continuity and reliability, costs and fees level of transit cargoes in development of Transit function of Georgia. 


\section{References:}

1. Bertsch, Gary K., Cassady Craft, Scott A. Jones and Beck, B. (2000), Crossroad and Conflict: Security and Foreign Policy in the Caucasus and Central Asia, New York, USA

2. Chagelishvili, L. (2009), Positioning the Economy of Georgia in conditions of Globalization, Journal - New Economist №3, Tbilisi, Georgia

3. Cornell S. E., (1999), Geopolitics and Strategic Alignmentsin the Caucasus and Central Asia Perceptions, Journal of International Affairs, Vol. IV, №2

4. Cornell, S. E., Tsereteli, M., Socor, V. (2005), Geostrategic implication of the Baku-Tbilisi-Ceyhan Pipeline: Oil Window to the west, Washington, USA

5. Danelia, I. (2016), Anaklia port and its prospects, http://forbes.ge/news/1309/anakliis-porti-da-misi-perspeqtivebi

6. Economic Comission for Europe, (2003), Environmental Performance Reviews - Georgia, UN, Chapter 13, "Transport and Enviropment", New York and Geneva

7. Gegeshidze, A. (2007), Promoting development of Georgia's transit role with regard to regional integration - EU Neighborhood Policy and Georgia (Analysis of Independent Experts), Tbilisi, Georgia

8. Hunter, Shireen T., (2000), Evolution of the Foreign Policy of the transcaucasian states. In Crossroads and Conflict: Security and Foreign policy in the Caucasus and Central Asia, Rourledge, New York, USA

9. Javakhishvili, R. (2009), Georgia's transit-service function, International Scientific-Analytical Journal "Economist" №1, Tbilisi, Georgia

10. Lissac, S. (2008), The Baku-Tbilisi-Kars railroad and its Geopolitical implications for the South Caucasus, Caucasian review on International Affairs, Vol. 2.

11. Michael P. Croissant, (2007), U.S. interests in the Caspian Sea Basin", Journal - Comparative Strategy

12. Minasyan, S. (2016), Armenia and Georgia: Transit potential in the context of trade-economic and political cooperation of the two countries http://regional-dialogue.com/geo-arm/

13. Natroshvili, N. (2015), APM Terminals" plans to build Mega Port in Poti http://www.netgazeti.ge/GE/105/business/45909/

14. National Center for Educational Quality Enhancement, (2015), Transportation Logistics, Tbilisi, Georgia

15. http://vet.ge/wp-content/uploads/2015/08/studentis-saxelmdzgvanelosatransporto-lojistika.pdf 
16. Shepard, W. (2017), How Azerbaijan, Georgia, And Turkey Subverted Russia And Isolated Armenia With New Railway, Forbes https://www.forbes.com/sites/wadeshepard/2017/10/30/new-silkroad-azerbaijan-georgia-and-turkey-unite-over-new-rail-linearmenia-further-isolated/\#1 adefdb3aff0

17. Uysal, O. (2013), Completely False Facts About Marmaray, Rail Turkey

18. www.apmterminalspoti.com

19. www.batumiport.com

20. www.batumioilterminal.com

21. www.economy.ge

22. www.fitchratings.com

23. www.geostat.ge

24. www.gogc.ge/ge/

25. www.kulevioilterminal.com

26. www.railway.ge

27. www.traceca-org.org 